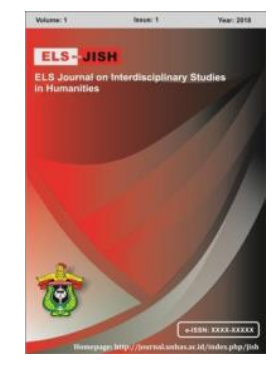

ELS-JISH

ELS Journal on Interdisciplinary Studies on Humanities

Volume 3 Issue 2, 2020

ISSN (print) : 2621-0843

ISSN (online) : 2621-0835

Homepage : http://journal.unhas.ac.id/index.php/jish

\title{
Self Actualization in a Novel by Andrea Hirata's Laskar Pelangi
}

\author{
Dyah Puji Rahayu', Setya Yuwana ${ }^{2}$, Roni $^{3}$ \\ ${ }^{1}$ dyah.pujirahayu.unesa@gmail.com
}

\begin{abstract}
The purpose of this research is to describe the fulfillment of needs as a process of selfactualization of the main characters who support in the form of business, difficulties, and achievement. This research is a qualitative research with descriptive method. The data used in this study is verbal, in the form of words, phrases or sentences obtained from research data sources, namely the text of the novel Laskar Pelangi by Andrea Hirata.The research results show that lkal was able to actualize himself by getting a scholarship to study abroad after going through various failures such as being a badminton athlete and writer. Previously, lkal succeeded in fulfilling the first stage, namely his physiological needs by working as a letter sorter. Second, the safetyneeds achieved by relying on his own abilities so that lkal feels safe when doing his safetyneeds even though he must have discrimination from the head of the expedition. Third, the attainment of love needs and the existence achieved in a way loving his childhood friend, the love of his best friend, and family even by making various kinds of sacrifice. Fourth, Ikal can achieve the esteem needs by equip himself with some knowledge so as to get praise from the jury even though he previously had difficulty in dividing time between study and work.
\end{abstract}

Keywords: Physiological Needs, Safetyneeds, Love and Belongingness Needs, Esteem Needs, And Self-Actualization Needs

How to cite: Rahayu, P. D., Yuwana, S., \& Roni. (2020). Self Actualization in a Novel by Andrea Hirata's Laskar Pelangi. ELS Journal on Interdisciplinary Studies in Humanities, 3(2), 250-264. DOI: 10.34050/els-jish.v3i2. 10453

\section{Introduction}

Self-actualization is the culmination of a variety of needs in the hierarchy of needs. This need is quite difficult in its achievement because it need struggle and sacrifice to be able to achieve it. Sometimes they will also experience many failures in the process. According to Rogers (in Baihaqi: 2008) self-actualization has three characteristics; (1) it is not static, but goes on, (2) the process is very difficult sometimes painful, (3) be your "self". They will not be hypocritical of themselves.

The average person who wants to actualize himself wants to show that they can become their own "self." Moreover, these individuals have backgrounds from families that are lacking. This reason would be a strong whip for them. They will "show off" with a variety of potential possessed. From people 
who are not "nobody" to "who he is". There is encouragement in him that "its me, I am successful now". Especially before they have been able to meet their needs in terms of physiological, feel that their position is safe, loved and love many people, have the ability to get praise from others, so they feel happy. Until in the end they want to perfect their happiness by actualizing themselves.

Psychological conditions like this are reflected in the character Ikal in the novel Laskar Pelangi by Andrea Hirata. Ikal is a figure of youth who have the determination to actualize themselves. Ikal is laborer's child of PT. PN. The family's mediocre economic conditions, can not sustain all kinds of family needs, especially if you only rely on wages from his father. Seeing the background of his family, whose lives were not successful, Ikal decided to move from Belitong to Bogor with the aim of changing his destiny to become a successful person and at the same time can meet all kinds of needs. The first step taken was to work as a mail sorter at the post office. Ikal tries to endured various difficulties even when he has to wake up early in the morning and walk against the cold air, down the river to get to work. In fact he also received discrimination from his coworkers. But Ikal tried to survive all.

A variety of ways Ikal did to be able to change his life better. Ikal once tried to realize some of the potential that he had, such as being a badminton athlete, book writer even though in the end the book he wrote was rejected by the publisher because it was not in accordance with the trend of books favorite at that time. Ikal realized that he could not keep falling down and he wanted to improve his life to be even happier. So, Ikal decided to look for another way, namely get an education scholarship abroad.

As long as humans are breathing, they will continue to coexist with what is called necessity. They will feel less or not fulfilled their needs. Based on the synopsis, lkal is so hard working to meet all his needs. These needs are innate needs that are necessary to be fulfilled. The innate needs according to Maslow (in Feist: 2014) consist of needs: physiological, safety, love and belongingness, eteem, and self-actualization.

Physiological needs, safety, love and belongingness, eteem, are called deficit needs or D-needs. If someone experiences a shortage of one of these needs, then they will experience a deficit and feel they need it. Conversely, if someone feels fulfilled those four needs, then those needs are no longer drive or motivating. Maslow considers all four needs as needs to survive. Whereas selfactualization needs are growth motivation which is the opposite of D-needs.

According to Maslow (in Goble: 2002) the hierarchy of needs should not be viewed in a rigid manner because those needs may arise in no order. It could be that basic needs have been fulfilled or at least a little satisfied so that they no longer motivate fulfillment. If so, then only the needs that are fulfilled will motivate their fulfillment.

If seen from the synopsis of the novel, there is a similarity background place in the novel with residence of the author, Belitong. Andrea Hirata who came from Belitong tried to raise the condition of the society that was happening at that time into a novel called Laskar Pelangi and of course by adding fantasy in it. This shows that Literature is a verb language that represents the mind of a 
writer who usually contains several literary experiences which he outlined in his fictional character (Rokhmansyah: 2014).

The background of the Laskar Pelangi novel is made as an object of research because: first, the novel contains elements or events that are experienced by many people. Second, the whole story through the characters can educate someone in understanding human behavior. Third, the novel is also tinged with emotional outbursts and motivation to fight for and realize one's talents. Fourth, the human character created by writers through the characters in the story can inspire the reader to fight for and try to be able to show his ability to get recognition. Based on several arguments presented, the researcher uses the novel Laskar Pelangi by Andrea Hirata as the object of research that is focused on the drive to fulfill the hierarchy of needs as a process of self-actualization.

\section{Method}

This research use desciptive qualitative approach. It is said descriptive research because in general the data are described not in the form of numbers but in the form of words in a note, photo, recording, and document (Semi, 1993: 24). The aim is to describe the data in words which are expected to clarify the form studied in a research.

In research, data is a source of information that will be used as material for analysis. The data used in the form of verbal, in the form of words, phrases or sentences obtained from research data sources, namely the text of the novel Laskar Pelangi by Andrea Hirata published by PT. Spread Library in 2014.

The data accumulation technique used is the documentation technique. Documents used include library documents. Library document technique consists of several stages, namely reading, takes notes and identifying data. Furthermore, existing data are analyzed by linking the data with the theory used so that conclusions can be drawn.

\section{Results and Discussion}

Novel Laskar Pelangi by Andrea Hirata tells the story of a young man who struggles to actualize himself. Process after process is lived by going through various obstacles that prevent it. When discussing needs, every individual has a variety of needs. These needs are made up of the weak to the strongest. Schultz (in Minderop: 2011) argues that needs are innate from humans since they were born into the world, from the weakest to the strongest which are all likened to stairs. These weak needs should be fulfilled first before the strong needs cling to them. This is the reason that makes lkal bother fulfilling their needs one by one. The following will explain the needs that drive lkal to fulfill them.

\subsection{Physiological Needs}

Living in a lack of economic conditions, make lkal has many shortcomings. One of them is physiological needs. Therefore, Ikal tried to meet his needs by working at the post office. Ikal moved to Bogor and became a letter sorter at the Post Office. Like the following data excerpt: 
Dan kembali aku termangu-mangu menatap tiga karung surat tadi. Setelah terpuruk dikhotbahi nyonya itu aku masih harus bekerja keras menyortir semuanya karena pukul delapan seluruh pengantar kilat khusus termin pertama akan berangkat dan karena aku adalah pegawai pos, tukang sortir, bagian kiriman peka waktu, shift pagi, yang bekerja mulai subuh. (Andrea Hirata, 2007:438).

[And again I was stunned staring at the three sacks of the letter earlier. After falling preached by the madam I still had to work hard to sort everything because at eight o'clock, all the first class delivery specials would depart and because I was a postal employee, sorter, part-timesensitive shipment, morning shift, who started working at dawn] (Andrea Hirata, 2007:438)

The data can be interpreted that Ikal's effort in fill up his physiological needs is by working as a mail sorter at the post office. Even lkal is in the morning shift which is mostly avoided by post office employees because they have to leave earlier than normal working hours. So he had to go to work while people were still fast asleep. Like the following data excerpt:

...Aku bangun pagi-pagi buta ketika orang-orang Bogor masih meringkuk di tempat tidur mereka yang nyaman. Aku merangkak-rangkak kedinginan, terseok-seok menuju kantor pos melewati bantaran Kali Ciliwung yang masih diliputi kabut untuk kembali menyortir ribuan surat... (Andrea Hirata, 2007:442).

[... I woke up very early in the morning when the Bogor people were still huddled in their comfortable beds. I crawled cold, stumbling towards the post office past the banks of the Ciliwung River which was still covered in fog to re-sort thousands of letters ...] (Andrea Hirata, 2007:442).

The data can be interpreted as difficulties experienced by Ikal when he became a sorter in the first shift. Ikal have to walk strong and fight the cold air of the city of Bogor in the morning. The harshness of life lived by lkal did not allow him to laze on the bed.Based on human desires that are motivated by the fulfillment of these physiological needs, an attempt will be made to struggle to meet them, which then appears the term strugle for survival. This is because these needs are primary needs that affect a person's physical condition (Sardiman, 2012: 82).So it's only natural that lkal struggles without knowing the time in order to meet his physiological needs. The term "hard work will not betray the results" apparently has been proven by lkal. The wages he earns from working as a letter sorter can be used to meet his physiological needs. Like the following quote:

Aku mengenakan pakaian rapi dan untuk pertama kalinya. Berdasi, memakai sedikit minyak wangi, dan menyemir sepatu. Pulpen di saku dan kubawa map yang tak tahu berisi apa. Aku telah menjadi tipikal orang muda yang spekulatif. Sebuah pemandangan yang menyedihkan sesungguhnya (Andrea Hirata, 2007:438).

[I wore neat clothes and for the first time. Tie up, wear a little perfume, and polish shoes. A pen in my pocket and I carry a folder that doesn't know what it contains. I have become a typical 
speculative young person. A sad sight indeed] (Andrea Hirata, 2007: 438).

The data can be interpreted that lkal was able to buy good clothes for the first time even complete with perfume and shoes that he used to go. This indicates that Ikal has managed to at least meet its own clothing needs. Inversely proportional to food needs. In this issue, Ikal is not able to buy food, but his breakfast needs are diverted by his piling work. So he turned his breakfast into work. Like the following quote:

...Sejenak aku benci pada hidupku yang kacau balau. Salah satu ciri hidup yang tak sukses adalah menerima semprotan pelanggan sebelum sempat sarapan pagi. Tapi sekian lama bekerja di sini aku telah terlatih memadamkan sementara fungsi gendang telinga. Maka madam itu hanya kulihat bergetar-getar seperti Greta Garbo dalam film bisu hitam putih (Andrea Hirata, 2007:438).

[... For a moment I hated my chaotic life. One characteristic of an unsuccessful life is receiving customer spray before you have breakfast. But for a long time working here I have been trained to temporarily extinguish the eardrum function. So madam was only seen trembling like Greta Garbo in a silent black and white film] (Andrea Hirata, 2007: 438).

The data can be interpreted that the time of breakfast lkal distracted by the work that piled up because he was in the morning shift which forced him to work quickly because he had to be sent right then and there. From here it was not possible for Ikal to not be able to buy food, but he turned it into work so that it would be finished quickly. This is in accordance with the opinion (Goble: 2002) that there are also people who satisfy their appetite by other means of diverting into other activities, such as smoking or drinking water. That way they can at least overcome the hunger they feel. Based on this opinion lkal diverted it into work.

\subsection{Safety Needs}

Security needs to be achieved Ikal is in terms of work. The first shift's work schedule makes lkal vulnerable to making mistakes because he has to work faster. So he also asked the head of the expedition for help. Like the following quote:

Telah tiga kali aku keliru minggu ini. Alasanku karena overload. Dahroji, ketua ekspedisi, tak mau tahu kesulitanku. Volume surat meningkat tajam dan banyak perluasan wilayah yang membuka wijk baru yang tak kukenal. Aku memandang kuyu pada tiga karung surat bercap Union Posttale Universele ketika nyonya yang masih seksi itu komplain... (Andrea Hirata, 2007:438).

[I have been mistaken three times this week. My reason is because of overload. Dahroji, head of the expedition, did not want to know my difficulties. The volume of letters increased sharply and many areas of expansion opened up new unknown landscapes. I looked haggardly at the three sacks of Union Posttale Universele letters 
when the lady who was still sexy complained ...] (Andrea Hirata, 2007: 438).

The data can be interpreted that Ikal is experiencing difficulties related to his work due to the large volume of letters while he only works alone and also the new rules about the expanded shipping area, making lkal feel difficult because his energy does not meet and he also has not memorized the distribution of new delivery destinations. So he could get a reprimand from the customer.As a result of the problems he was facing, he tried to ask for help from the head of the expedition. However, Dahroji as chairman did not want to provide assistance to Ikal. This is an act of discrimination against one's work. Based on these data, it can be concluded that the security needs of Ikal cannot be met in full because security needs are not like physiological needs that can be met at any time.Because no one can really feel himself safe or one hundred percent safe (Feist \& Feist, 2014: 333). That is, people will never be completely protected from meteors, fires, floods or other dangerous events.

\title{
3.3 Love and Belongingness Needs
}

Being loved and loving is the most important thing for psychological health. Especially if the figure is needed by people who are loved, especially families. This is what lkal tried to do to try to love and accept the weaknesses and strengths of his family. One of them was Ikal who tried to finance his niece's education because his father was laid off by PT. PN. So Ikal tried to take over his brother's responsibility. Like the following quote:

\begin{abstract}
Lelah seharian bekerja lenyap jika melihat Eryn dan semangat belajarnya, jiwa posotifnya, dan intelegensia yang terpancar dari sinar matanya. Aku rela kerja lembur berjam-jam, membantu menerjemahkan bahasa Inggris, menerima ketikan, dan berkorban apa saja-termasuk baru-baru ini menggadaikan sebuah tape deck, hartaku yang paling berharga-demi membiayai kuliahnya...(Andrea Hirata, 2007:443).

[Tired days of work vanished if he saw Eryn and his enthusiasm for learning, his positive spirit, and intelligence emanating from his eyes. I am willing to work long hours, help translate English, accept typing, and sacrifice anything - including recently pawning a tape deck, my most valuable treasure - to pay for his studies .... (Andrea Hirata, 2007: 443) .
\end{abstract}

The data can be interpreted as Ikal's efforts in loving his family. As an uncle who loves his nephew, he works hard to meet all the needs related to his niece's education. Even the data also implies Ikal's difficulty in financing Eryn's education. Ikal until willing to work overtime and find side jobs in order to make ends meet. But everything Ikal did happily because of the love factor that was so strong towards Eryn. Ikal's hard work paid off, Ikal Eryn could not be separated from Ikal's figure. Even Eryn depends on Ikal. This is seen in the following data excerpt:

Eryn memintaku cuti untuk mengantarnya ke rumah sakit jiwa itu. Apa dayaku menolak, bukankah semuanya memang untuk 
mendukung dirinya. Lagi pula Sungai Liat ada di Pulau Bangka, tetangga Pulau Belitong. Kami akan sekalian pulang kampung setelah ia riset (Andrea Hirata, 2007:446).

[Eryn asked me to leave to take her to the mental hospital. What is my power to refuse, isn't everything really to support him. Moreover, Sungai Liat is on Bangka Island, neighboring Belitong Island. We will all return home after he researches] (Andrea Hirata, 2007: 446).

The data can be interpreted that Eryn is very dependent on his uncle. Eryn asked lkal to take time off and drive her to do research. This proves that Eryn cannot do his work without the figure of Ikal as his uncle. Ikal has replaced the figure of his father. Because of his love for his niece, lkal decided to take time off and accompany Eryn to do research. This sense of dependency with each other shows the existence of a strong affection between Ikal and his niece, Eryn. In addition, Ikal also received love from his best friend. Like the following quote:

Sekarang kami duduk di beranda sebuah rumah panggung kuno khas Melayu, rumah ibu Ikal.

"Bagaimana kabarnya si lkal itu, Ibunda?" tanya Mahar kepada ibu Ikal (Andrea Hirata, 2007:492).

[Now we sit on the veranda of an old Malay traditional stilt house, the home of Ikal's mother.]

["How are the Curls, Mother?" asked Mahar to Ikal's mother] (Andrea Hirata, 2007: 492)

The data can be interpreted that lkal really missed his figure by his best friend. His friends loved lkal so much that he came to his house and asked his mother about Ikal's news. The love that Ikal gets is truly extraordinary. He is surrounded by people who love him. However, this is inversely proportional to the love story with her partner. Ikal always fails in love even though he had a relationship with a childhood friend. Like the following quote:

Aku tersenyum mengenang nostalgia di Toko Sinar Harapan dan teringat bahwa dulu aku pernah memiliki cinta yang ternyata tak hanya sedalam lubuk kaleng-kaleng cat yang sampai sekarang masih berjejal-jejal di situ. Aku juga merasa beruntung telah menjadi orang yang pernah mengungkapkan cinta. Masih terasa indahnya sampai sekarang. Merasa beruntung karena kejadian itu merupakan tonggak bagaimana secara emosional aku telah berevolusi. Dan agaknya cinta pertamaku dulu amat berkesan karena ia telah melambungkanku ke puncak kebahagian sekaligus membuatku menggelongsor karena patah hati di antara keranjang buah mengkudu busuk di toko itu (Andrea Hirata, 2007:456).

[I smiled reminiscing about the nostalgia at the Sinar Harapan Shop and remembered that I once had a love that was not only as deep as the paint cans which are still crowded there. I also feel fortunate to have been someone who has expressed love. It still feels beautiful 
until now. Feeling lucky because that event was a milestone in how emotionally I had evolved. And it seems that my first love was very memorable because he had catapulted me to the top of happiness and at the same time made me sag because of a broken heart between a rotten noni fruit basket in the shop] (Andrea Hirata, 2007: 456).

The data can be interpreted that Ikal had felt the beauty of having love with a friend during his childhood. Love is so great that it cannot be forgotten. Even lkal still feels great love when remembering the figure of the woman. However, his first love also at the same time broke his heart because it had been abandoned by a woman he loved. There is a desire to establish relationships with others, so they will work hard to realize the relationship they dream of and hope to find a place between them. Because if it is not achieved, they will feel something is missing in them. Maslow (in Goble: 2002) argues that people who are thirsty for love are a kind of disease because of lack. Like the word "like lack of salt or vitamins". Therefore, Ikal tries to have a relationship again with women, but the result is the same, he is abandoned by the woman he loves. Like the following quote:

...Meskipun kemudian setelah dewasa beberapa kali cinta memperlakukan aku dengan amat buruk, aku tetap percaya pada cinta. Semua itu gara-gara wanita berparas kuku ajaib di Toko Sinar Harapan itu. Kemana gerangan ia sekarang? Aku tak tahu dan tak mau tahu. Gambaran cinta seindah lukisan taman bunga karya Monet itu biarlah seperti apa adanya. Kalau aku menjumpai A Ling lagi bisa-bisa citra lukisan itu pudar karena mungkin saja $A$ Ling sekarang adalah $A$ Ling dengan parises, selulit, pantat turun, susu kempes, gemuk, perut buncit, dan kantong mata. la dulu adalah venus dari Laut Cina Selatan dan aku ingin tetap mengenangnya seperti itu (Andrea Hirata, 2007:457).

[... Even though after growing up several times love treated me very badly, I still believed in love. All because of the woman with the magic nails in the Sinar Harapan Shop. Where on earth is he now? I don't know and I don't want to know. The picture of love as beautiful as a flower garden painting by Monet let it be as it is. If I see A Ling again, the image of the painting might fade because maybe $A$ Ling is now A Ling with parises, cellulite, buttocks, deflated milk, fat, distended abdomen, and eye bags. He used to be venus from the South China Sea and I want to keep remembering it like that] (Andrea Hirata, 2007: 457).

The data can be interpreted that Ikal failed in establishing love with the woman he loved. But all of them received gracefully because he had felt love so beautiful from the figure of a woman and her little friend. This means that sincere love will leave an eternity in people's minds.

\subsection{Esteem Needs}


The appreciation needs is closely related to one's confidence. The more abilities a person has, the more confident his disposition. Conversely, if someone does not have any ability, they will think pessimistic, even unproductive. Ikal as a letter sorter, does not want to just stand idly by accepting the fate of being a letter sorter. He tried to equip himself with some knowledge. Like the following data excerpt:

...Aku membaca sebanyak-banyaknya buku. Aku membaca buku sambil menyortir surat, sambil makan, sambil minum, sambil tiduran mendengarkan wayang golek di radio FM. Aku membaca buku di dalam angkutan umum, di dalam jemban, sambil mencuci pakaian, sambil dimarahi pelanggan, sambil disindir ketua ekspedisi, sambil upacara Korpri, sambil minum air, atau sambil memperbaiki atap bocor. Bahkan aku membaca sambil membaca. Dinding kamar kostku penuh dengan gambar grafiti rumus-rumus kalkulus, GMAT, dan aturan-aturan tenses. Aku adalah pengunjung perpustakaan LIPI yang paling rajin dan shift subuh yang dulu sangat kubenci sekarang mala kuminta karena dengan demikian aku dapat pulang lebih awal untuk belajar di rumah. Jika beban pekerjaan demikian tinggi aku membuat resume bacaanku dalam kertas-kertas kecil, inilah teknik jembatan keledai yang dulu diajarkan Lintang padaku. Kertas-kertas kecil itu kubaca sambil menunggu ketua pos menurunkan kantongkantong surat dari truk. (Andrea Hirata, 2007:458)

[... I read as many books. I read a book while sorting letters, while eating, while drinking, while lying down listening to puppet show on FM radio. I read books on public transportation, in bridge, while washing clothes, while being scolded by customers, while being teased by expedition leaders, while Korpri ceremonies, while drinking water, or while repairing a leaky roof. Even I read while reading. The walls of my boarding room are full of graffiti, calculus formulas, GMAT, and tenses rules. I am the most diligent visitor of the LIPI library and the dawn shift which I hated so much now that I asked because because then I could go home early to study at home. If the workload is so high I make my reading resume in small pieces of paper, this is the donkey bridge technique that Lintang had taught me. I read the small papers while I waited for the postmaster to unload mail bags from the truck.] (Andrea Hirata, 2007: 458)

The data can be interpreted as Ikal's motivation in equipping him with a variety of very large knowledge. He doesn't know the place when it comes to studying. He even had difficulty in dividing time between studying and work. Both he united as long as he can learn. Ikal's hard work paid off until he was successfully praised by his proposal's board of examiners. Like the following quote:

"Saya tertarik dengan motivation letter Anda, alasan dan cara Anda menyampaikannya dalam kalimat Inggris sangat mengesankan." Katanya. ["I'm interested in your motivation letter, the reasons and the way you say it in English are very impressive." He said.] 
Aku kembali tersenyum, kali ini senyum khas penjual asuransi. [1 smiled again, this time the typical smile of the insurance seller.]

"Belum tahu dia, orang Melayu lincah benar bersilat kata," kataku dalam hati. ["Don't know him yet, the agile Malay is true to words," I told myself.]

Lalu sang mantan menteri membuka proposal penelitianku yang berisi bidang yang akan kutekuni, materi riset, dan topik tesis dalam pendidikan beasiswa nanti. [Then the former minister opened my research proposal which contained the fields I would pursue, research material, and thesis topics in scholarship education later.]

"Ahhhh, ini juga menarik...."(Andrea Hirata, 2007:458). ["Ahhhh, this is also interesting ..."] (Andrea Hirata, 2007: 458).

The data can be interpreted as a compliment given by the board of examiners to Ikal. In fact, according to the English language testing board and the discussion material of the proposal, it is also very interesting to become research material. This compliment makes Ikal confident and optimistic that the work he is doing will succeed. Maslow (1954) argues that people whose selfesteem is sufficient, give rise to self-confidence and positive thinking. This means they can work and do things that are positive. Conversely, if the price is low, it can lead to despair which causes them to distrust their abilities. To have self-esteem requires a strong effort, for example to equip yourself with a variety of abilities both science or other expertise so that others cannot underestimate themselves. The examiner even said that he had been waiting for a research proposal with this kind of material. Like the following data excerpt:

Saya telah lama menunggu ada proposal riset semacam ini, ternyata datang dari seorang pegawai kantor pos! Ke mana kau pergi selama ini anak muda?" (Andrea Hirata, 2007:462)

[I have been waiting for this research proposal for a long time, but it came from a post office employee! Where did you go all this time young man? "] (Andrea Hirata, 2007: 462)

The data can be interpreted as praise given by the board of examiners to lkal. The examiner did not think that such a good proposal was written by a post office employee. This is why everyone must equip themselves with science. No matter what our work or social status, as a social person is obliged to equip himself with knowledge.

\subsection{Self-Actualization Needs}

Ikal is classified as people who have high creativity. Even he is classified as someone who is not afraid to fall, is responsible for his work, and is also willing to accept the advice of others. He prepared more than one plan to develop his potential if he fails. Plan A is to become a badminton athlete. Ikal in the field of sports can be said to be successful even received many awards. Like the following quote:

Kesimpulan itu kuperoleh karena aku selalu menjadi juara pertama pertandingan bulu tangkis kelurahan $U 19$ dan pialanya berderet- 
deret di rumahku. Piala itu demikian banyak sampai ada yang dipakai ibuku untuk pemberat tumpukan cucian, ganjal pintu, dan penahan dinding kandang ayam. Ada juga piala yang dipakai menjadi semacam palu untuk memecahkan buah kemiri, dan sebuah piala berbentuk panjang bergerigi dari pertandingan terakhir sering dimanfaatkan ayahku untuk menggaruk punggungnya yang gatal (Andrea Hirata, 2016:340).

[I got that conclusion because I always won first place in the U19 urban badminton competition and the trophies were lined up in my house. There were so many cups that my mother used them to weigh the piles of laundry, prop the door and hold the walls of the chicken coop. There is also a trophy that is used as a hammer to break the candlenut, and a long jagged cup from the last match is often used by my father to scratch his itchy back] (Andrea Hirata, 2016: 340).

The data can be interpreted that Ikal has the potential to become a badminton athlete. Various championship tournaments he participated in even he always won in every match that he participated in. However, being an athlete cannot be done forever because athletes usually have an age limit. When he exceeds his age limit, he must be ready to be replaced by other young athletes whose abilities are better than he. In addition, the older an athlete's age, his energy and ability decreases. Ikal was well aware of the risk, until in the end he decided to try his Plan B, which is to become a book writer. The book he wrote is also not far away with the topic of badminton sports. Like the following quote:

Buku itu sebenarnya telah selesai kutulis, tidak tanggung-tanggung, seluruhnya mencapai 34 bab dan hampir 100.000 kata. Untuk menulisnya aku telah melakukan riset yang intensif di federasi bulu tangkis dan komite olahraga nasional serta mengamati kehidupan sosial beberapa mantan pemain bulu tangkis terkenal. Aku juga telah mempelajari budaya pop serta tren terbaru pengembangan kepribadian.Tapi para penerbit tak sudi menerbitkan bukuku berdasarkan pertimbangan komersial. Mereka lebih tertarik pada karya-karya sastra cabul, yaitu buku-buku yang penuh tulisan jorok seperti kondom, masturbasi, dan orgasme karena buku-buku semacam itu lebih mendatangkan keuntungan. Mereka, para penerbit itu, telah melupakan prinsip-prinsip men sana in corpore sano (Andrea Hirata, 2007:439).

[The book was actually completed, not half-hearted, totaling 34 chapters and nearly 100,000 words. To write it, I have done intensive research in the badminton federation and the national sports committee and observed the social lives of several well-known former badminton players. I have also studied pop culture and the latest trends in personality development. But the publishers do not want to publish my book based on commercial considerations. They are more interested in obscene literary works, which are books full of dirty writing such as condoms, masturbation, and orgasm because such books are more profitable. They, the publishers, have forgotten 
the principles of men sana in corpore sano] (Andrea Hirata, 2007: 439).

The data can be interpreted that Ikal has the potential to become a writer. Ikal managed to write several books about the world of badminton and personality. Ikal is even very responsible for his work so that he conducts various kinds of research related to the topic to be written so that his work can be held accountable for its contents. Unfortunately, this work of Ikal cannot be accepted by publishers because it is considered not in accordance with the trend of books that are in demand in the market. So the publishers are afraid that the Ikal's book will not sell well in the market. Ikal tried to understand the condition. This incident taught that in fact he did not know everything, and this experience taught that others were able to teach him something. So Ikal tried to be humble.

Everyone when experiencing failure must feel hopeless. Likewise with Ikal. he felt frustrated with his efforts that always failed. But he tried to calm down and try to accept the conditions he was experiencing. The characteristic of people who self-actualize is that their level of conflict is low, they do not fight against themselves but their personality is united. They have more energy for productive purposes. Ikal got up and tried everything to show the potential he had. Ikal also decided to draw up plan $\mathrm{C}$, which is to continue his education. Like the following data excerpt:

Seminggu setelah kulemparkan naskah bulu tangkisku ke Kali Ciliwung aku membaca sebuah pengumuman beasiswa pendidikan lanjutan dari sebuah negara asing. Aku segera menyusun rencana $C$, yaitu aku ingin sekolah lagi! Kemudian setelah itu tak ada satu menit pun waktu kusia-siakan selain untuk belajar... (Andrea Hirata, 2007:458).

[A week after I threw my badminton script at Ciliwung River, I read an announcement of further education scholarship from a foreign country. I immediately drew up a plan C, i want to go to school again! Then after that there wasn't even a minute of wasted time aside from studying .... (Andrea Hirata, 2007: 458).

The data can be eaten up by Ikal's effort to rise from adversity by compiling a new plan that is, continuing his education. Ikal discarded all the books he wrote and reorganized his life. When he read an announcement about an overseas education scholarship, he decided to continue his education again. No day is passed without learning. He was serious about getting the scholarship. Like the following data excerpt:

"Aku harus mendapatkan beasiswa itu!" demikian kataku dalam hati setiap berada di depan kaca.

Aku benar-benar bertekad mendapatkan beasiswa itu karena bagiku ia adalah tiket untuk meninggalkan hidupku yang terpuruk. Lebih dari itu aku merasa berutang pada Lintang, A Ling, Pak Harfan, Bu Mus, Laskar Pelangi, Sekolah Muhammadiyah, dan Herriot (Andrea Hirata, 2007:460). 
["I have to get the scholarship!" I said in my heart every time in front of the glass.

I was really determined to get the scholarship because to me it was a ticket to leave my fallen life. More than that I feel I owe it to Lintang, A Ling, Pak Harfan, Mrs. Mus, Laskar Pelangi, Muhammadiyah Schools, and Herriot] (Andrea Hirata, 2007: 460).

The data can be interpreted that lkal sees life clearly and as it is. Evidenced by the fact that lkal realized that he could not always be down with a condition that was never what he expected. So Ikal decided to continue his education which had stopped. Ikal is determined to get a scholarship to study abroad. Ikal considers that with the scholarship he can continue his life better. In addition, he also felt indebted to the teacher and his friends to live better and be useful for many people. Ikal also took various tests to get the scholarship. Like the following data excerpt:

\begin{abstract}
Kemudian tes demi tes yang mendebarkan berlangsung selama berbulan-bulan, diawali dengan sebuah tes penyaringan pertama di sebuah stadion sepak bola yang dipenuhi peserta. Hampir tujuh bulan kemudian aku berada pada tahap yang disebut penentuan terakhir. Penentuan terakhir merupakan sebuah wawancara di sebuah lembaga yang hebat di Jakarta. Wawancara akhir ini dilakukan oleh seorang mantan menteri yang berwajah tampan tapi senang bukan main pada rokok (Andrea Hirata, 2007:69).
\end{abstract}

[Then the test after the thrilling test lasted for months, beginning with a first screening test at a soccer stadium filled with participants. Nearly seven months later I was at the stage called final determination. The final determination was an interview at a great institution in Jakarta. The final interview was conducted by a former minister with a handsome face but happy not to play with cigarettes] (Andrea Hirata, 2007: 69).

The data can be interpreted as Ikal's effort to get his scholarship by taking part in the various tests that were held. The road to success is not easy, because it must spend energy and time long enough. Ikal went through all that patiently. He passed the exam after exam and time after time he passed with great hope that he would get the scholarship. Like a the saying "the business will not deny the results", finally Ikal managed to get the scholarship. Like the following data excerpt:
Maka tak lama kemudian aku telah menjadi mahasiswa. Meskipun hanya langkah kecil aku merasa telah membuat sebuah kemajuan dan sekarang aku dapat menilai hidupku dari perspektif yang sama sekali berbeda... (Andrea Hirata, 2007:462).

[So soon I was a student. Even though it was only a small step I felt I had made progress and now I can assess my life from a completely different perspective ... ](Andrea Hirata, 2007: 462).

The data can be interpreted that the Ikal's effort finally paid off. Ikal managed to get a scholarship to study abroad. This scholarship seems to have changed 
Ikal's thoughts about the life he had been living. He felt that his life was going much better. The way to actualize yourself is not easy. It takes a process and hard work. If we try seriously, then we will get far better results.

\section{Conclusion}

Novel Laskar Pelangi by Andrea Hirata is a novel that tells the story of a young man who struggles hard to actualize himself. The story in this novel is also not much different from the real life of humans in general. How does the effort and difficulties in the process for the process of meeting all the needs escape. How is the efforts of young people who are struggling hard to be able to succeed amidst all-round family conditions. Can reflect literature is a reflection of real life.

Based on the results of research and discussion, it can be concluded that as a process of self-actualization, Ikal is able to meet the needs that drive to be met such as physiological needs, love \& presence needs, appreciation needs, and self-actualization needs.

Related to physiological needs, by trying to work as a mail sorter at the post office, Ikal is able to meet his physiological needs, namely buying good clothes. The difficulty is going to work early in the morning. Regarding security needs, it does not mean that Ikal does not feel safe, but that he only feels anxious about the conditions of his work that demand to use speed and accuracy in working, so that Ikal is worried if he makes a mistake. However, as already explained that the security needs cannot be met completely, Ikal tried to be careful. So from here it can be concluded that the needs of lkal Security are slightly met.

Love and existence needs, Ikal can be from family, friends and girlfriends. The difficulty in meeting the needs of love for the family is that lkal works hard to pay for his niece's education because he has taken over his brother's responsibilities. While his love story did not go smoothly because it was always decided by his girlfriend. However, his first love is able to provide a positive outlook related to love. While the need for appreciation can be met by equipping themselves with various kinds of knowledge so as to get praise from the board of examiners for its ability. The difficulty of equipping oneself with the knowledge is to divide the time of work and study, so that the impression is mixed.

The pinnacle of various kinds of needs is the achievement of selfactualization needs. Process after process is passed with various failures that are passed. Starting from being a badminton athlete who ultimately could not continue. Become an author of a book, which in the end could not be published. Until finally decided to look for scholarships to study abroad which can eventually be achieved.

The suggestion for other researchers is that this research can be used as reference material. However, it is necessary to develop a theory or discussion of security needs, because researchers also feel that there are still many shortcomings that need to be developed in terms of security needs. So it would be nice there are researchers who can develop 


\section{References}

Baihaqi, MIF. (2008). Psikologi Pertumbuhan: Kepribadian Sehat untuk Mengembangkan Optimisme. Bandung: PT. Remaja Rosdakarya.

Feist, J \& Feist, G. J. (2014). Theories of Personality, $7^{\text {ed }}$ ed (Handriatno.). Jakarta: Salemba Humanika.

Goble, F. G. (2002). The Third Force, The Psichology of Abraham Maslow (Supratinya, Drs. A.). Yogyakarta: Kanisius.

Hirata, A. (2007). Laskar Pelangi. Yogyakarta: PT. Bentang Pustaka.

King, L. A. (2010). The Science of Psychology: An Appreciative View (Marwensdy, Brian, S. Psi.). Jakarta: Salemba Humanika.

Maslow, A. H. (1945). Motivation and Personality. New York: Harper \& Row.

Minderop, A. (2011). Psikologi Sastra. Jakarta: Yayasan Pustaka Obor Indonesia.

Rokhmansyah, A. (2014). Study dan Pengkajian Sastra; Perkenalan Awal Terhadap IImu Sastra. Yogyakarta: Graha IImu.

Sardiman, A.M. (2012). Interaksi \& Motivasi Belajar Mengajar. Jakarta: PT. Raja Grafindo Persada.

Semi, A. (1993). Metode Penelitian Sastra. Bandung : Angkasa. 